\title{
Investigation of Micro Hardness, Cooling Rate and Microstructure of ATIG Welded samples of Al-SiC composite
}

\author{
Sivachidambaram Pichumani ${ }^{1}$, Raghuraman Srinivasan ${ }^{2}$, Venkatraman Ramamoorthi ${ }^{3}$. \\ School of Mechanical Engineering, SASTRA Univeristy, Thanjavur, India - 613401.
}

\begin{abstract}
Activated TIG welding has been performed on $\mathrm{Al}-8 \% \mathrm{SiC}$ composite $5 \mathrm{~mm}$ plate with various fluxes such as $\mathrm{Al}_{2} \mathrm{O}_{3}, \mathrm{MnO}_{2}, \mathrm{CaO}, \mathrm{MgO}, \mathrm{SiO}_{2} \& \mathrm{TiO}_{2}$, to study \& analyze the Microstructure, Micro hardness and cooling rate. Correlation study between micro hardness, microstructure and cooling rate for Constant Current TIG welding and Activated TIG welding on Al-SiC composite are also carried out to analyze the relation between the effect of cooling rate on microstructure \& the effect of microstructure on micro hardness. The experimental results of ATIG welding on $\mathrm{Al}-\mathrm{SiC}$ composite shows fine grain weld microstructure on $\mathrm{ATIG}-\mathrm{SiO}_{2} \& \mathrm{ATIG}-\mathrm{TiO}_{2}$, which results in higher micro hardness. Micro hardness values are taken in different locations of weld surface at $1 \mathrm{~mm}, 2 \mathrm{~mm} \& 3 \mathrm{~mm}$ below the weld surface and the same is also observed along the weld zone to heat affected zone upto $12 \mathrm{~mm}$ for the center of the weldment. Minimum micro hardness values found in ATIG $-\mathrm{MnO}_{2}, \mathrm{ATIG}-\mathrm{CaO} \& \mathrm{ATIG}-\mathrm{MgO}$ are due to intermediate micro structure between coarse and fine in heat affected zone. ATIG $-\mathrm{Al}_{2} \mathrm{O}_{3}$ weld zone \& heat affected zone and heat affected zone of ATIG $-\mathrm{MnO}_{2}$, ATIG - $\mathrm{CaO} \& \mathrm{ATIG}-\mathrm{MgO}$ shows coarse microstructure leading to reduction in micro hardness value. Cooling rate for the different CCTIG \& ATIG welding are recorded and correlation between the micro structures are studied. Coarse micro structure in weld zone and heat affected zone have least cooling rate whereas fine micro structure in weld zone resulted at higher cooling rate. Heat affected zone strongly depends on temperature gradient between the weld center and weldment's heat affected zone.
\end{abstract}

\section{Introduction}

Gas Tungsten Arc Welding (GTAW) also known as Tungsten Inert Gas (TIG) welding showed high quality weld than other arc welding process. Since non ferrous metals requires quality weld with reduced defects and improved mechanical properties of the weld, TIG welding is considered to be more suitable and appropriate welding process. However, its shallow weld penetration causes lesser production rate. Increase in weld passes for thick sections lead to higher input in the weld which reduces the weld strength [1] due to the formation of coarse grain microstructure [2].

To reduce the heat input into weld the Activated TIG welding (ATIG) a new variant was found out. ATIG welding process was developed in early 1960's by the Paton Welding Institute, Ukraine to improve the weld penetration $[3,4]$. By improving the weld penetration, number weld passes get reduced by reducing the weld pass the heat input given the weld material is also get reduced [5]. The activated flux TIG welding may have two types of mechanisms that are mostly accepted, first one is based on the reverse Marangoni convection effect[6-8], and the other one is based on arc construction effect $[9,10]$.

Active flux coated on the weld increases the penetration by following the theory of reverse
Marangonic effect proposed by Helipe \& Roper[11-13] and arc constriction effect as stated by Lucas \& Howse[14,15]. Due to the constricted arc \& reverse Marangonic effect the weld penetration is observed [16].

\section{Experiments}

Autogenous welding was performed on $\mathrm{Al}-8 \% \mathrm{SiC}$ composite material with a plate thickness of $5 \mathrm{~mm}$ using ADOR CHAMPTIG 300AD welding machine [17]. Other welding parameters considered during welding are provided in Table 1. Welded samples are shown in Figure $1-2$.

Table 1: Welding parameter during CCTIG and ATIG welding

\begin{tabular}{cc}
\hline Parameter & Condition \\
\hline Current Type & AC Current \\
Constant Current TIG & $110 \mathrm{~A}$ \\
Electrode Diameter & $3.2 \mathrm{~mm}$ \\
Electrode Material & $2 \% \mathrm{Th}-\mathrm{Tungsten}$ Electrode \\
Arc Length & $2 \mathrm{~mm}$ \\
Arc Voltage & $18 \mathrm{~V}$ \\
Welding Speed & $2 \mathrm{~mm} / \mathrm{s}$ \\
Argon Flow Rate & $18 \mathrm{I} / \mathrm{min}$ \\
Active Layer Coating & $0.5-1 \mathrm{mg} / \mathrm{cm}^{2}$ \\
Active fluxes & $\mathrm{Al}_{2} \mathrm{O}_{3}, \mathrm{CaO}, \mathrm{MgO}, \mathrm{SiO}_{2}, \mathrm{TiO}_{2} \& \mathrm{MnO}_{2}$ \\
Heat Input & $990 \mathrm{w}$ \\
\hline
\end{tabular}


During welding, cooling rate at $10 \mathrm{~mm}$ away weld zone was calculated from time - temperature profile acquired using data acquisition system (DAQ) through LabView software coupled with National Instrument NI cDAQ 9174 kit which employs a temperature acquiring module -NI 9211 with K type thermocouple.

Using standard metallographic procedure the welded samples were prepared for microstructure observation from microscopic image analyzer. Vickers micro hardness of different region such as weld zone, heat affect zone and base material were measured with load of $500 \mathrm{~g}$ with 10 seconds as indentation time performed using Shimadzu micro hardness tester.

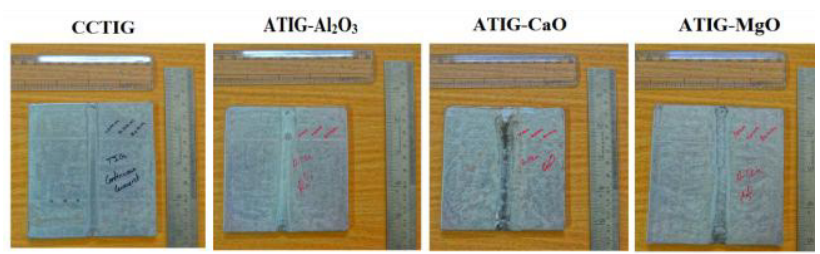

Figure 1: Welded samples of CCTIG, ATIG- $\mathrm{Al}_{2} \mathrm{O}_{3}$, ATIG-CaO and ATIG-MgO
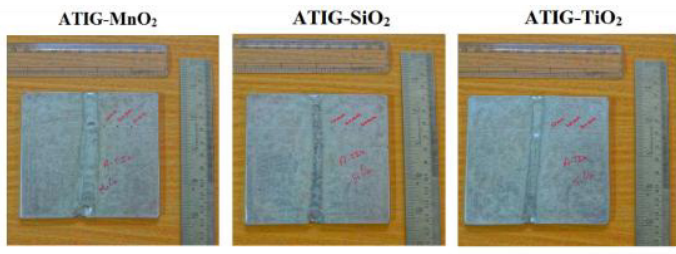

Figure 2: Welded samples of ATIG-TiO 2, ATIG-SiO 2 and ATIG- $\mathrm{MnO}_{2}$

\section{Results \& Discussion}

\subsection{Micro hardness - CCTIG \& ATIG welded samples}

Table 2 shows the average micro hardness value of CCTIG \& ATIG weldment on weld centre, $3 \mathrm{~mm}$ away from weld centre \& $7 \mathrm{~mm}$ away from weld centre. Standard deviation is also tabulated. Figure 3, shows the micro hardness $1 \mathrm{~mm}$ below the weld surface. Figure 4 shows the micro hardness value $2 \mathrm{~mm}$ below the weld surface. Figure 5 shows the micro hardness values of $3 \mathrm{~mm}$ below weld surface. Here micro hardness values are observed in different locations from weld centre to $12 \mathrm{~mm}$ away from the weld centre. Micro hardness value did not have much change after $10 \mathrm{~mm}$ away from the weld centre which is more or less equal to the base material micro hardness.

Table 2: CCTIG \& ATIG welded samples micro hardness

\begin{tabular}{|c|c|c|c|c|c|c|}
\hline \multirow[t]{2}{*}{$\begin{array}{l}\text { Welding } \\
\text { conditions }\end{array}$} & \multicolumn{2}{|c|}{$\begin{array}{c}\text { Weld centre } \\
\text { (HV) }\end{array}$} & \multicolumn{2}{|c|}{$\begin{array}{c}3 \mathrm{~mm} \text { away from weld } \\
\text { centre (HV) }\end{array}$} & \multicolumn{2}{|c|}{$\begin{array}{l}7 \mathrm{~mm} \text { away from } \\
\text { weld centre (HV) }\end{array}$} \\
\hline & Average & $\begin{array}{l}\text { Standard } \\
\text { deviation }\end{array}$ & $\begin{array}{c}\text { Averag } \\
\text { e }\end{array}$ & $\begin{array}{l}\text { Standard } \\
\text { deviation }\end{array}$ & $\begin{array}{l}\text { Avera } \\
\text { ge }\end{array}$ & $\begin{array}{l}\text { Standard } \\
\text { deviation }\end{array}$ \\
\hline CCTIG & 60.21 & 0.61 & 57.61 & 1.19 & 53.92 & 2.23 \\
\hline ATIG-Al ${ }_{2} \mathrm{O}_{3}$ & 60.73 & 1.86 & 57.00 & 1.82 & 52.58 & 2.10 \\
\hline ATIG-CaO & 57.84 & 1.72 & 55.89 & 1.44 & 54.58 & 1.97 \\
\hline ATIG-MgO & 62.86 & 2.41 & 58.50 & 2.15 & 53.93 & 1.63 \\
\hline ATIG-SiO2 & 63.12 & 2.41 & 60.50 & 3.29 & 57.00 & 4.11 \\
\hline ATIG-TiO & 62.22 & 1.06 & 58.38 & 1.58 & 53.72 & 2.69 \\
\hline ATIG-MnO & 61.42 & 2.51 & 58.12 & 1.20 & 54.33 & 4.24 \\
\hline
\end{tabular}




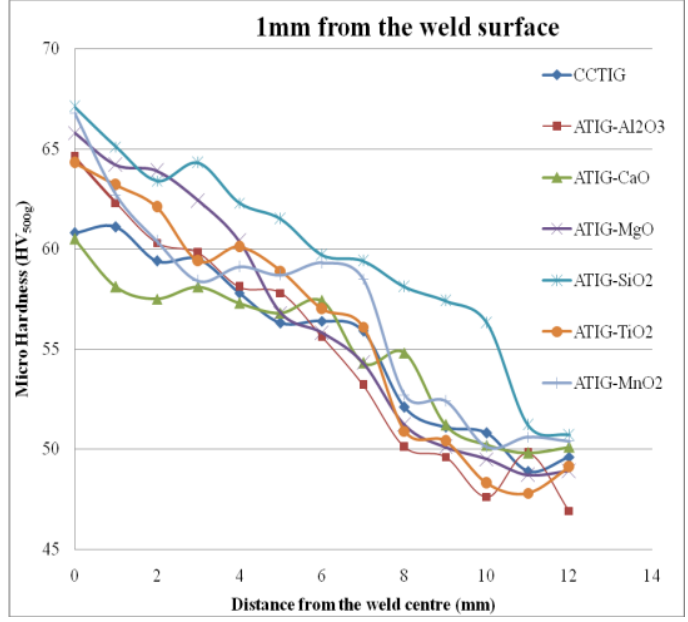

Figure 3: Micro hardness of CCTIG \& ATIG welded samples $1 \mathrm{~mm}$ below the weld surface



Figure 4: Micro hardness of CCTIG \& ATIG welded samples $2 \mathrm{~mm}$ below the weld surface

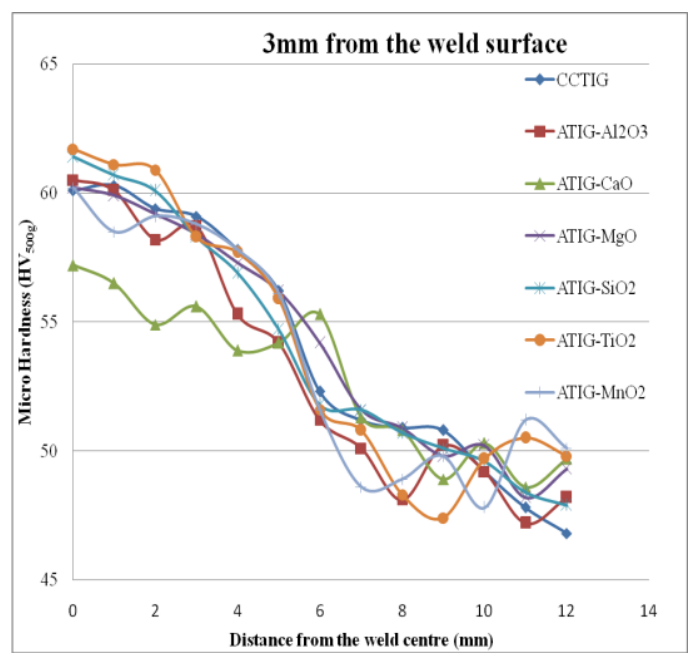

Figure 5: Micro hardness of CCTIG \& ATIG welded samples $3 \mathrm{~mm}$ below the weld surface

\subsection{Microstructure - Base material, CCTIG \& ATIG welded samples}
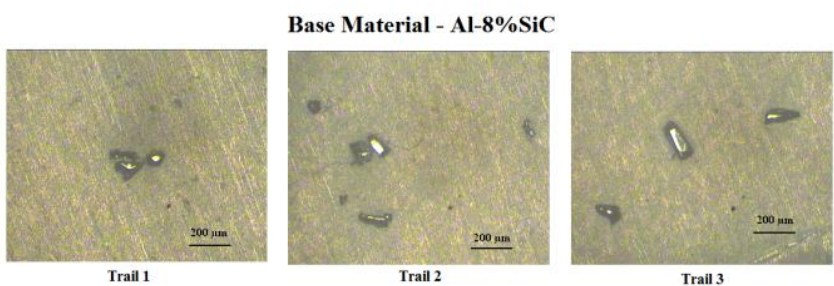

CCTIG
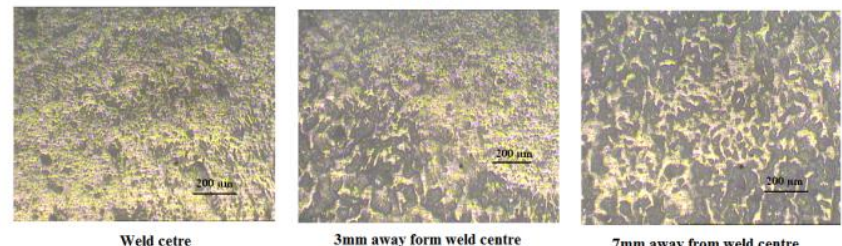

$7 \mathrm{~mm}$ away from weld centre

Figure 6: Microstructure of base material ( $\mathrm{Al}-8 \% \mathrm{SiC}$ composite), CCTIG welded samples

Figure 6, shows the micro structure of base material, CCTIG welded samples. Figure 7, shows ATIG - $\mathrm{Al}_{2} \mathrm{O}_{3}$, ATIG $-\mathrm{CaO} \&$ ATIG $-\mathrm{MgO}$ micro structure of weld zone, $3 \mathrm{~mm}$ away from weld zone $\& 7 \mathrm{~mm}$ away from the weld zone otherwise called as heat affected zone.
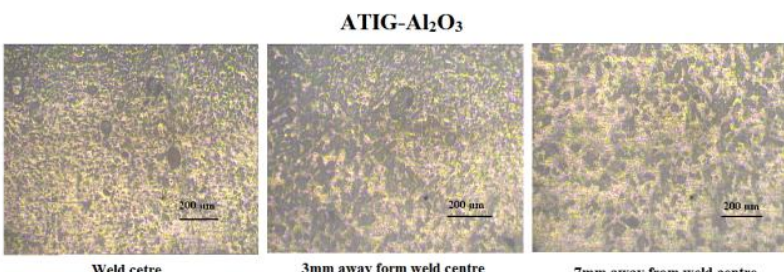

$3 \mathrm{~mm}$ away form weld centre

$7 \mathrm{~mm}$ away from weld centre

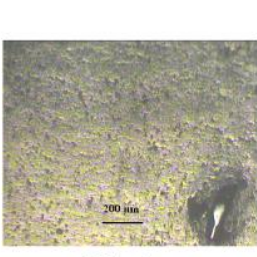

ATIG-CaO
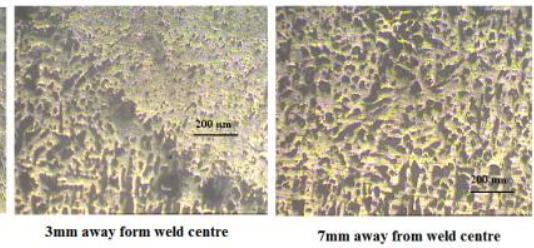

ATIG-MgO
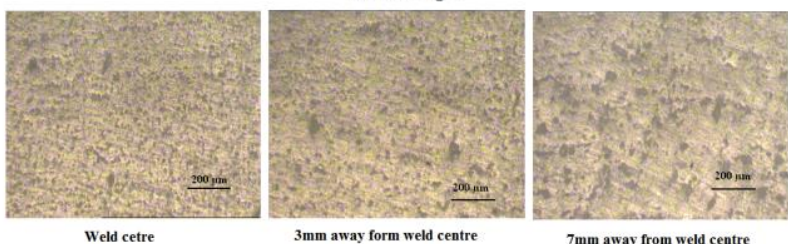

Figure 7: Microstructure of ATIG welded samples with active fluxes such as $\mathrm{Al}_{2} \mathrm{O}_{3}, \mathrm{CaO} \& \mathrm{MgO}$ 


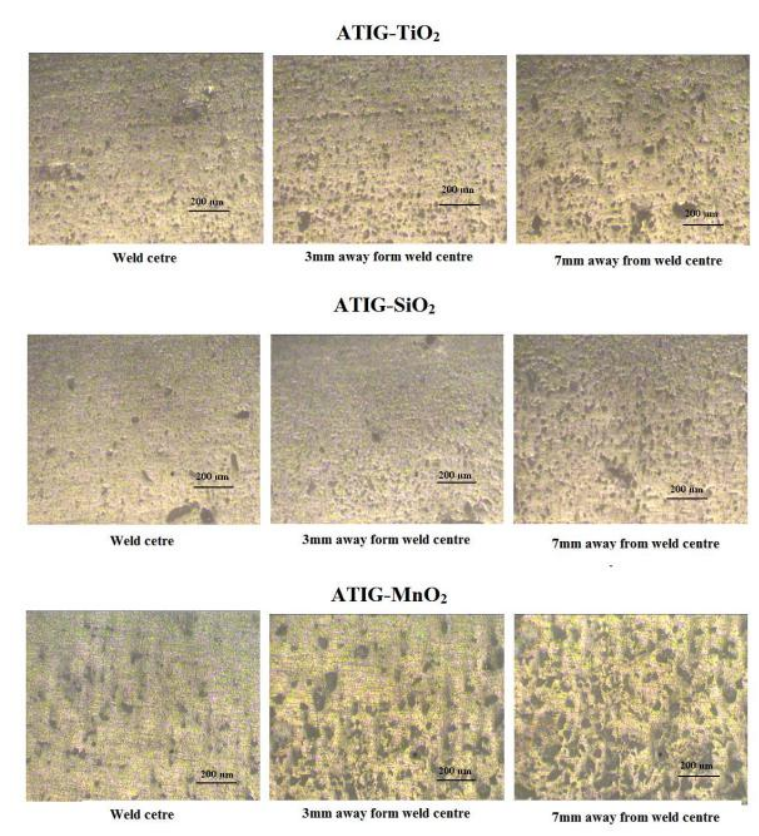

Figure 8: Microstructure of ATIG welded samples with active fluxes such as $\mathrm{TiO}_{2}, \mathrm{SiO}_{2} \& \mathrm{MnO}_{2}$

Figure 8 shows the micro structure of ATIG $-\mathrm{MnO}_{2}$, $\mathrm{ATIG}-\mathrm{SiO}_{2} \& \mathrm{ATIG}-\mathrm{TiO}_{2}$ weldments. From Figure 6 , the following results are observed, very fine grain microstructure is observed in base material and coarse grain size microstructure in weld zone and in HAZ. Figure 7 shows ATIG - $\mathrm{CaO} \& \mathrm{ATIG}-\mathrm{MgO}$ is also showed coarse grain structure which is similar to CCTIG welded microstructure. Intermediate size between fine and coarse microstructure is found in weld zone as well as in heat affected zone in ATIG - $\mathrm{MnO}_{2}$ \& ATIG $\mathrm{Al}_{2} \mathrm{O}_{3}$. Figure- 8 shows $\mathrm{ATIG}-\mathrm{SiO}_{2} \& \mathrm{ATIG}-\mathrm{TiO}_{2}$ is having fine grain microstructure in both weld zone and also in heat affected zone. Base material showed very fine grain microstructure.

\subsection{Cooling rate - CCTIG and ATIG welded samples}

Table 3 shows the cooling rate CCTIG \& ATIG weldments of various active fluxes are recorded and tabulated. Highest cooling rate is observed in ATIG-SiO2 followed by ATIG - TiO2 of $295 \mathrm{~K} / \mathrm{s} \& 290 \mathrm{~K} / \mathrm{s}$. Lowest cooling rate is observed in CCTIG \& ATIG - Al2O3 of $286 \mathrm{~K} / \mathrm{s} \& 283 \mathrm{~K} / \mathrm{s}$. Higher cooling rate produces the fine grain microstructure and lower cooling rate produces the coarse grain microstructure in weld zone and heat affected zone. This is due to the temperature gradient observed in weld zone and between weld zone \& heat affected zone.

Table 3: CCTIG \& ATIG welded samples cooling rate

\begin{tabular}{|c|c|c|c|c|c|c|c|}
\hline $\begin{array}{c}\text { PCTIG } \\
\text { welding } \\
\text { condition }\end{array}$ & TIG & $\begin{array}{l}\text { ATIG } \\
\mathrm{Al}_{2} \mathrm{O}_{3}\end{array}$ & $\begin{array}{l}\text { ATIG } \\
\mathrm{CaO}\end{array}$ & $\begin{array}{l}\text { ATIG } \\
\text { MgO }\end{array}$ & $\begin{array}{l}\mathrm{ATIG} \\
\mathrm{SiO}_{2}\end{array}$ & $\begin{array}{l}\text { ATIG } \\
\mathrm{TiO}_{2}\end{array}$ & $\begin{array}{l}\text { ATIG } \\
\mathrm{MnO}_{2}\end{array}$ \\
\hline $\begin{array}{c}\text { Rate of } \\
\text { cooling } \\
(\mathrm{K} / \mathrm{s})\end{array}$ & 286 & 283 & 287 & 286 & 295 & 290 & 287 \\
\hline
\end{tabular}

\section{Conclusion}

Correlation between micro hardness, microstructure and cooling rate of Constant Current TIG welding and Activated TIG welding on Al-SiC composite has been studied and validated.

Micro hardness are observed in three different locations of weld surface at $1 \mathrm{~mm}, 2 \mathrm{~mm} \& 3 \mathrm{~mm}$ locations below the weld surface and it also observed along the weld zone to heat affected zone upto $12 \mathrm{~mm}$ for the plotting the micro hardness value around the weldment.

Microstructure observed in weld centre of the weldment. The interaction of weld zone $\&$ heat affected zone occurs $3 \mathrm{~mm}$ away from the weld centre line and heat affected zone formation is $7 \mathrm{~mm}$ away from the weld centre line.

Minimum micro hardness value is found in ATIG $\mathrm{MnO}_{2}, \mathrm{ATIG}-\mathrm{CaO} \& \mathrm{ATIG}-\mathrm{MgO}$ due to intermediate micro structure between coarse and fine grain formation in heat affected zone. ATIG $-\mathrm{Al}_{2} \mathrm{O}_{3}$ weld zone \& heat affected zone and the heat affected zone of ATIG $-\mathrm{MnO}_{2}$, ATIG - $\mathrm{CaO} \&$ ATIG - MgO shows coarse microstructure, resulting in reduced micro hardness. ATIG welding on Al-SiC composite shows fine grain weld microstructure resulting in higher micro hardness on $\mathrm{ATIG}-\mathrm{SiO}_{2} \& \mathrm{ATIG}-\mathrm{TiO}_{2}$.

Cooling rate for the different CCTIG \& ATIG welding are recorded and correlation between the micro structures are studied. Coarse micro structure in weld zone and heat affected zone have least cooling rate. Fine micro structure in weld zone should have higher cooling rate. It is also inferred that heat affected zone directly depends on temperature gradient between the weld centre and weldment's heat affected zone.

\section{Acknowledgements}

This research work was funded by Management of SASTRA University and the authors gratefully acknowledge and thank the Vice Chancellor, SASTRA University, Thanjavur, India for the support and encouragement.

\section{References}

1. LEI Yu-cheng, YUAN Wei-jin, CHEN Xi-zhang, ZHU Fei, CHENG Xiao-nong, In-situ weld-alloying plasma arc welding of $\mathrm{SiC}_{\mathrm{p}} / \mathrm{Al} \mathrm{MMC}$, Transactions of Nonferrous Metals Society of China, 17, 2007, page $313-317$.

2. A. Urena, M.D. Escalera, L. Gil, Influence of interface reactions on fracture mechanisms in TIG arc-welded aluminium matrix composites, Composites Science and Technology, 60, 2000, page 613-622. (PII: S0266-3538(99)00168-2)

3. Selvi Dev, A. Archibald Stuart, R.C. Ravi Dev Kumaar, B.S. Murty, K. Prasad Rao, Effect of scandium additions on microstructure and mechanical properties of Al-Zn-Mg alloy welds, Materials Science and Engineering A, 467, 2007, page 132 -138. (doi:10.1016/j.msea.2007.02.080) 
4. R.I. Hsieh, Y.-T. Pan, H.-Y. Liou, The Study of Minor Elements and Shielding Gas on Penetration in TIG Welding of Type 304 Stainless Steel, Journal of Materials Engineering and Performance, 8(1), February 1999, page 68-74.

5. Z.D. Zhang, L.M. Liu, Y. Shen, L. Wang, Mechanical properties and microstructure of magnesium alloy gas tungsten arc welded with cadmium chloride flux, Material Characterization, 59, 2008, page 40-46.

6. Ding FAN, Ruihua ZHANG, Yufen Gu, Masao USHIO, Effect of Flux on A-TIG Welding of Mild Steels, Transaction of JWRI, 30, 1, 2001, page 3540.

7. Hidetoshi Fujii, Toyoyuki Sato, Shanping Lu, Kiyoshi Nogi, Development of an advanced A-TIG (AA-TIG) welding method by control of Marangoni convection, Material Science and Engineering A, 495, 2008, page 296-303. (Doi: 10.1016/j.msea.2007.10.116)

8. Shanping LU, Dianzhong LI, Hidetoshi Fujii, Kiyoshi Nogi, Time Dependant Weld Shape in Ar-O Shielded Stationary GTA Welding, Journal of Material Science and Technology, 23 (5), 2007, page 650-654.

9. Shanping Lu, Hidetoshi Fujii, Kiyoshi Nogi, Marangoni convection and weld shape variations in $\mathrm{He}-\mathrm{CO}_{2}$ shielded gas tungsten arc welding on SUS304 stainless steel, Journal of Material Science, 43, 2008, page 4583-4591. (Doi: 10.1007/s10853008-2681-3)

10. Shanping Lu, Hidetoshi Fujii, Kiyoshi Nogi, Marangoni convection and weld shape variations in Ar- $\mathrm{O}_{2}$ and $\mathrm{Ar}-\mathrm{CO}_{2}$ shielded GTA welding, Material Science and Engineering A, 380, 2004, page 290-297. (Doi: 10.1016/j.msea.2004.05.057)
11. Shanping Lu, Hidetoshi Fujii, Kiyoshi Nogi, Weld Shape variation and Electrode Oxidation Behavior under Ar-(Ar-CO2) Double Shielded GTA Welding, Journal of Material Science and Technology, 26 (2), 2010, page 170-176.

12. A. Berthier, P. Paillard, M. Carin, S. Pellerin, F. Valensi, TIG and A-TIG welding experimental investigations and comparison with simulation Part-2 - arc constriction and arc temperature, Volume 17, Number 8, 2012, Science and Technology of Welding and Joining, page 616-621.

13. S. Leconte, P. Paillard, J. Saindrenan, Effect of fluxes containing oxides on tungsten inert gas welding process, Volume 11, Number 1, 2006, Science and Technology of Welding and Joining, page 43-47.

14. Y.L. Xu, Z.B. Dong, Y.H. Wei, C.L. Yang, Marangoni convection and weld shape variation in A-TIG welding process, Volume 48, 2007, Theoretical and Applied Fracture Mechanics, page 178-186.

15. Kuang-Hung Tseng, Chih-Yu Hsu, Performance of activated TIG process in austenitic stainless steel welds, Volume 211, 2011, Journal of Materials Processing Technology, page 503-512.

16. Chunli YANG, Sanbao LIN, Fengyao LIU, Lin Wu, Qingtao ZHANG, Research on the Mechanism of Penetration Increase by Flux in A-TIG Welding, Journal of Material Science and Technology, 19,1, 2003, page 225-227.

17. Sivachidambaram Pichumani, Raghuraman Srinivasan, Effect of Pulsed Current and Activated Flux with TIG Welding on the Microstructure and Mechanical Properties of Al-SiC Composite, Indian Journal of Science and Technology, Vol. 8(27), 71559, October 2015, pp 1-6. 